\title{
The Impact of Business Strategic Orientation on Innovation-Driven Mergers and Acquisitions: An Empirical Study
}

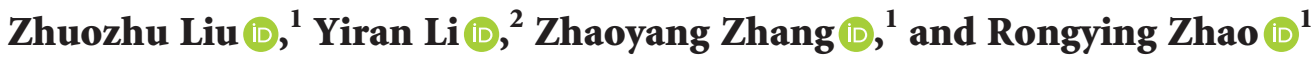 \\ ${ }^{1}$ School of Information Management, Wuhan University, Wuhan 430072, China \\ ${ }^{2}$ School of Management, Zhejiang University of Technology, Hangzhou 310014, China \\ Correspondence should be addressed to Rongying Zhao; zhaory@whu.edu.cn
}

Received 5 October 2021; Accepted 10 November 2021; Published 15 December 2021

Academic Editor: Daqing Gong

Copyright (c) 2021 Zhuozhu Liu et al. This is an open access article distributed under the Creative Commons Attribution License, which permits unrestricted use, distribution, and reproduction in any medium, provided the original work is properly cited.

The "innovation-driven" development approach plays a crucial role in transforming and developing current China's national economy. Many innovation-driven mergers and acquisitions (M\&As) emerge in the M\&As activities of firms, and the acquiring firm's business strategy of conducting innovation-driven M\&As has drawn significant attention. To study the impact of business strategy on innovation-driven M\&As, this paper adopts the probit model to conduct logistic regression analysis on the $223 \mathrm{M} \& A s$ data samples, exploring which business strategy is inclined to perform innovation-driven M\&As. The results show that prospective firms are more likely to conduct innovation-driven M\&As. Besides, the firms that conduct prospective business strategies are more likely to have a higher innovation level than firms operating defensive business strategies. The innovation level plays the role of a mediator variable in the model of business strategies influencing innovation-driven M\&As. This paper analyzes the innovationdriven motivation from the perspective of business strategy, enriching the research of M\&A and offering a method to predict the possibility of innovation-driven M\&A by measuring business strategy.

\section{Introduction}

The "innovation-driven" development mode has become a critical path for China's current transformation and development. At the current development stage of China, only innovation can bring long-lasting momentum for the country's development. General Secretary Xi Jinping emphasized the importance of innovation-driven development and the necessity of promoting innovation-driven growth to facilitate a steady global recovery in the 13th BRICS Summit, and innovation-driven development has then been elevated to the height of national strategies [1]. China's development was once factor-driven. China is now conducting an innovation-driven development strategy, and China's economic structure has been converted to the innovationdriven mode. Innovation has become the main driver of China's economic development, but the share of primary and secondary industries is relatively high compared to developed countries [2]. Previous mergers and acquisitions market achieved arbitrage by occupying market share and alliance between strong firms, but it is limited [3], now the mergers and acquisitions (M\&A) market will keep pace with China's innovation-driven development that is aiming to achieve profit by raising the innovation level.

Business strategy is an important factor in determining the direction of a company's development, while M\&A is considered as a foremost business strategic alliance for firms in the global market [4]. Although the business strategies of M\&As are investigated theoretically and practically [5-9], most of this research focuses on the purpose and motivation of M\&As, and there are few works on the impact of business strategic orientation on types of M\&As. This paper studies the impact of different business strategies on innovationdriven M\&As and tries to verify whether the business strategies affect innovation-driven mergers and acquisitions by taking innovation level as a mediator variable. 


\section{Literature Review}

2.1. M\&As. Mergers and acquisitions (M\&As) of firms have always been a hot research topic in the economic field. Most research literature focused on researching the performance of M\&As and the factors affecting M\&As, and the purpose of $M \& A$ is to enhance the influence of firms in the industry, increase the market share, and bring more economic benefits to the acquiring firm $[6,8,10,11]$. In the mid- to late $1980 \mathrm{~s}$, research of M\&As was incorporated into the framework of strategic management. The strategic school focused on the impact of M\&As on individual firms, and the key point is the impact of correlation or strategic matching on M\&A performance [12]. Singh and Montgomery [12] examined the impact of the types of M\&As on the success of the behavior. In a case study of 203 merged firms from 1970 to 1978, the value created by related M\&As was higher than that of diversified M\&As. Strategic matching is concerned with the degree of enhancement and complementarity to the acquiring firm in the aspects of industries, markets, or technologies $[13,14]$.

Meanwhile, many scholars also conducted many studies comparing different kinds of M\&A and reached three conclusions: Firstly, related M\&As are better than diversified M\&As, and both are the same in creating value for shareholders [10]. Related diversified firms are more profitable and are in more profitable industries than unrelated diversified companies [15], but bankruptcy risk is significantly lower in diversified firms $[16,17]$. Secondly, both unrelated M\&As and related M\&As create value, but unrelated M\&As destroy some value when acquisitions happen $[11,18]$.

The above literature studies show a close relationship between the M\&A model, M\&A performance, and firm strategy. However, there is a lack of literature on the relationship between M\&As and business strategy.

2.2. Business Strategic Orientation. The organizational strategy model proposed by Miles and Snow [19] and Miles et al. [20] specifically categorizes the business strategic orientation. The model examines the differences between different strategically oriented firms in financial reporting violations and whether the business strategy can determine the need for a firm's financial status for audit work. Porter [21] distinguished between different business strategies based on cost leadership and product differentiation. Based on the consideration of the relationship between business strategies and audit work, Miles and Snow [19] categorize and elaborate on the following three types of firms: prospector, defender, and analyzer. The strategy type is a continuum with a prospector at one end of the continuum and a defender at the other. The prospective firms strive to be the leaders in the innovation market, while defensive companies usually compete in terms of the product price, product quality, and service to secure a stable market share. Bentley et al. [22] quantified Miles and Snow's strategy classification [19] by scoring six financial indicators, that is, RDS, EMPS, $\mathrm{REV}, \mathrm{MS}$, EMPF, and CI, to measure different strategies. These financial indicators were calculated based on the rolling average of the previous five years [23].
With strong R\&D capabilities and diverse technologies, prospective firms are committed to exploring new markets and developing new products [24]. In search of innovation and opportunities in the market, firms adopting prospective strategies strive to develop new technologies and offer new services [20]. Walker et al. [25] believe that firms with prospective strategies need to strengthen product R\&D and engineering. The higher the firm's investment in $R \& D$, the better the firm's earnings. Therefore, firms adopting a prospective strategy will be more inclined to carry out innovation-driven M\&As, expand innovation capabilities in M\&As, and improve the level of their research and development. On the contrary, as a type of firm that avoids risks, defensive firms always want to maintain their relatively stable product position in a relatively independent market. They often resort to continuous and reliable means such as efficient production and strict control to protect their market position [26].

Following the categories of the business strategic orientation from Miles \& Snow [19] and Bentley et al. [22], Safi et al. [27] analyzed the business strategies of Chinese companies listed on the Shenzhen and Shanghai stock exchanges over the period 2006-2019 and found that prospectors are more likely to suffer from the risk of a share price collapse. Magerakis and Habib [28] examined the difference in environmental protection between prospectors and defenders. Using a large sample of US corporate data from 1990 to 2014, they found that defenders emit more toxic chemicals than prospectors.

Liu and Kong [29] examined the impact of business strategy on sustainability. They found that prospectors have much less sustainable business behavior than defenders. Choi and Park [30] studied the effect of a firm's business strategy on audit report lag. They found that the degree of aggressiveness of business strategy was positively associated with audit report lag, and the degree of conservatism of business strategy was negatively associated with audit report lag.

The above literature empirically differentiates prospective strategy from defensive strategy in the audit report, risktaking, and driving force of innovation. However, there is a lack of literature on the relationship between business strategic orientation and M\&A.

2.3. Innovation-Driven $M \& A s$. As a new concept, the innovation-driven M\&As can be understood in comparison with a similar approach of M\&As that was previously studied in the academic field, that is, the BKT (Based on Knowledge and Technology) mergers and acquisitions strategy. Autio and Laamanen [31] defined a "technology-driven acquisition" as acquiring control of a target company's business by acquiring all or a majority of the target company's shares and ultimately acquiring new knowledge and technology from the target company. Many scholars have cited this concept in their research on innovation and M\&As [32-35]. M\&As aim to acquire new knowledge and technology, accelerate innovation, and allow firms to gain external support. The innovation-driven M\&A studied in this paper is exactly this 
kind of knowledge- and technology-based M\&A. This type of M\&A is widely adopted by large companies in the world today. It is one of the most important ways for companies to acquire external technology. Ahuja and Katila [36] divided acquisitions into technology-driven and non-technologydriven ones and studied the influence of M\&A of chemical firms on innovation performance. The empirical research on 72 firms found that non-technical driven M\&A has no significant impact on the firm's innovation output. At the same time, the technology-driven M\&A can positively promote the firm's technological innovation. Bena and Li [37] argue that M\&As with the purpose of acquiring knowledge and technology are common among firms. Grandstand et al. [38] rated the importance of the M\&A approach in 42 countries worldwide and concluded that BKT M\&A gained increasing importance in developed countries such as the US and Japan. Ahuja and Katila [36] suggest that after acquiring core technologies from different firms, the acquiring firm has a different perspective on R\&D, which leads to a significant increase in its R\&D and technological innovation capabilities.

There are many studies of M\&As aiming to acquire new knowledge and technology, but there is a lack of research defining the innovation-driven M\&A type. From previous research, innovation-driven M\&As can be defined as the M\&As that aim to acquire leading new products, new technologies, and new production processes to create profit. Innovation can come from the inside of the firm, manifested as the R\&D investment to improve production technology and improve the technological level of the product. Innovation can also come from the acquisitions of external objects, acquiring new technologies and products of the target firm through M\&As. Kalafut and Low [39] believed that innovation capital is an intangible asset that significantly impacts the development of a firm and makes an important contribution to future earnings. China's central government proposed the innovation-driven development approach at the Party's 18th Congress, but innovation has always been a hot topic for corporate development and economic transformation [1].

\section{Hypothesis Development}

3.1. Business Strategy and Innovation-Driven M\&A. The $M \& A$ is a kind of activity of investment, and the innovationdriven M\&A is an activity of investment aiming to obtain leading new products, new technologies, and new processes. Agrawal et al. [40] studied the profitability of the principal acquiring firms for 1-5 years after the occurrence of M\&A. The study found that neither diversified M\&As nor sameindustry M\&As would bring long-term objective income to the principal merging parties. On the contrary, they can cause losses to the firm. Innovation-driven M\&A is riskier than other types of M\&A because there is no guarantee that the new technologies and products acquired after the M\&A will be converted into profits. Navissi et al. [41] provided evidence that an innovation-oriented prospective strategy is more likely to overinvest because prospective strategies are willing to undertake the risk of investment $[19,23]$.
This paper classifies listed companies into three categories based on Miles \& Snow [19] and Bentley et al.'s [22] strategic models and divides firm strategies into prospective strategy, defensive strategy, and analytic strategy. We believe that exploratory companies are more likely to undertake innovation-driven M\&A than defensive companies. Thus, hypothesis 1 is as follows:

Hypothesis 1. Prospective business strategies are more likely to conduct innovation-driven M\&A than defensive business strategies.

\subsection{Business Strategic Orientation and Innovation Level.} If business strategies vary in the likelihood of engaging innovation-driven M\&A, we expect that different firms have different innovation levels based on their business strategies.

The prospective firms are more radical and usually innovative enterprises. They have great enthusiasm for the introduction of new knowledge and the development of new products and new markets $[19,20]$. Committed to discovering and excavating new products and new market opportunities, the prospective firms, with the core capability of market capabilities and R\&D capabilities, are adventurous and can provide innovative products $[25,26]$. They may have more technology types and longer product lines [24]. Therefore, firms adopting a prospective business strategy focus on new technologies or services, which inevitably leads to radical innovations that help them grasp new opportunities in the market. Therefore, prospective firms may be more innovative than defenders, and they are more willing to do radical innovations, such as innovation-driven M\&As.

In contrast, the defenders are relatively defensive enterprises, and do not tend to take risks to invest in financing [42]. Prospective firms quickly transform the market portfolio of their products into innovative leaders in many areas, while defenders compete on the basis of price, service, or quality to maintain their position in the narrow and stable market $[19,20]$. Defenders are more willing to improve their internal production efficiency and reduce costs. They are more cautious about innovative corporate behaviors, so they may not be willing to conduct innovation-driven M\&As.

Our study suggests that prospective business strategies are more likely to conduct innovation-driven M\&A than defensive business strategies in hypothesis 1 . If it is true, acquiring firms will have more opportunities to get knowledge and patents from acquired firms. Then, prospective firms' innovation level is expected to be higher than defenders, which is stated formally in the following hypothesis:

Hypothesis 2. Prospective business strategies are more likely to have a higher innovation level than defensive business strategies.

\subsection{Business Strategy, Innovation Level, and Innovation-} Driven $M \mho A$. We suppose that business strategies vary in their level of innovation and likelihood of engaging innovation-driven M\&A. In that case, we expect firms with 
higher innovation levels to be more willing to conduct an innovation-driven M\&A. We hope to find a mediating variable between innovation-driven M\&A and business strategy to directly influence innovation-driven M\&A. If innovation level is associated with innovation-driven M\&A, it is probably the mediator variable of enterprise strategy's influence on knowledge-transfer M\&A.

Based on data for listed Chinese A-share manufacturing firms for 2008 to 2018, Li et al. [43] found that business strategy and corporate innovation show an inverted U-shaped relationship. Corporate risk-taking plays a mediating role between business strategy and innovation performance. Seru [44] believed that BTK M\&As are inherent in enterprise innovation and that the level of enterprise innovation may affect the BTK M\&As. Thus, if Hypothesis 2 is true, we expect that innovation level is associated with innovation-driven M\&As. Hypothesis 3 is as follows:

Hypothesis 3. Business strategies influence innovationdriven M\&A by taking innovation level as a mediator variable.

\section{Research Methodology}

4.1. Data Collection. This study selected 2869 M\&A cases from the CSMAR database, which contain parameters such as the stock code of the acquiring company, the timing of the M\&A announcement, the payment method, and the financial indicators of the scoring strategy. The industry classification for this study follows the 2012 version of the industry classification standards issued by the China Securities Regulatory Commission. The paper scores firms by the ranking of financial indicators in their industries. According to their strategies, M\&A firms are divided into three categories: prospective firms, analytical firms, and defensive firms. The paper mainly studies the impact of prospective strategy and defensive strategy on innovationdriven M\&As.

This paper mainly takes the M\&As of prospective and defensive firms as research samples. Whether an acquisition is innovation-driven or not is based on the content of the announcement made during the mergers and acquisitions. We read the M\&A announcement of the subject company to understand the purpose of the acquisition. Then, we analyzed the purpose of the M\&A to determine whether the M\&A implied a strategic consideration of acquiring new technologies, new products, and new markets. Finally, we determined that the company has increased its $\mathrm{R} \& \mathrm{D}$ capabilities through the acquisition. After defining the above parameters and identifying the type of M\&A, we labeled innovation-driven M\&A.

4.2. Measurements of Business Strategic Orientation. As shown in Figure 1, we distinguished prospective strategy from defensive strategy using a discrete strategic combination model proposed by Bentley et al. [22]. We scored each company based on its 5-year moving average ranking within

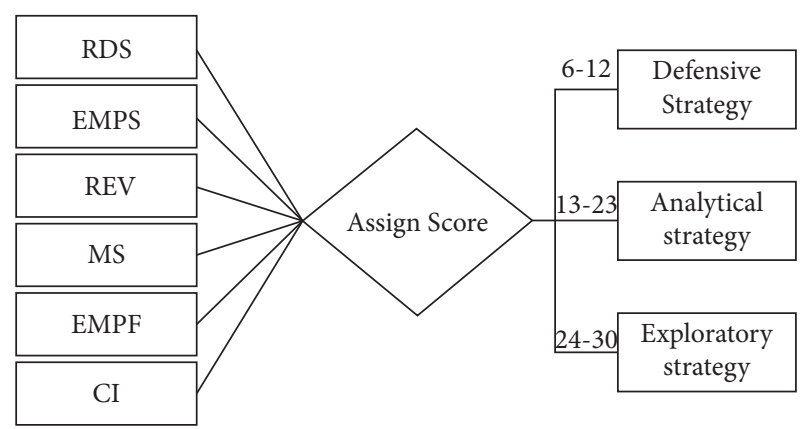

FIgURE 1: Discrete strategic combination model.

its industry across six financial indicators. Due to the limited data, this paper uses the three-year moving average of each indicator as the final value to participate in their industry ranking. We used hierarchical four-digit SIC (Standard Industrial Classification). The highest level of industry code consists of two digits, and the number will be further increased by the second and third levels, whose codes consist of three digits and four digits, respectively.

Similar to Ittner et al. [23], Bentley et al. [22] used six indicators, that is, RDS, EMPS, REV, MS, EMPF, and CI, to measure business strategic orientation. The specific explanation of these six indicators is shown in Table 1. In this paper, companies are first ranked in their industry by six financial indicators. The rankings are divided into quintiles. Each indicator is assigned a value based on its position, with the highest quintile receiving a score of five and the lowest a score of one. Indicators ranked in the first quintile are assigned a score of 1 , those in the second quintile are assigned a score of 2, and so on. Capital intensity is scored inversely, with the highest (low) quintile observation given a score of 1 (5). The other five indicators are given a score of 5 (1) based on the highest (low) quintile observation. The final score for each company is a summation of six financial indicator scores, with a maximum of 30 and a minimum of 6 . Companies can be classified into the following three categories based on their strategy scores: defender (6-12), analyzer (13-23), and prospector (24-30).

4.3. Probit Model. Since the dependent variable of this paper is a $0-1$ variable, the regression model should choose either a logit regression model or a probit regression model. Relying on Wooldridge [45], we use the probit model rather than the logit model. In $y^{*}=x^{\prime} b+e$, the distributions of $e$ in logit and probit regressions are different; that is, $e$ obeys a logistic distribution in the logit model and a standard normal distribution in the probit model. Assuming that the objective function is $\left[{ }^{*}\right]$, we take the value of 1 when the event in $\left[{ }^{*}\right]$ is correct, and 0 is used in other cases. Therefore, if $y^{*}>0, y$ is 1 , and if $y \leqq 0, y$ is 0 . We assume that $e$ is independent of $x$ and obeys the standard logistic distribution or standard normal distribution. In either case, $e$ is distributed symmetrically to 0 . Economists tend to assume the normal assumptions of $e$. Therefore, the probit model is used more commonly in the econometric than in the logit model. The probit model is used in this paper because the random variables in the 
TABLE 1: Indicators for measuring business strategic orientation.

\begin{tabular}{lc}
\hline Name & Meaning \\
RDS & The ratio of research and development to sales \\
EMPS & The ratio of employees to sales \\
REV & A historical growth measure (one-year percentage change in total sales) \\
MS & The ratio of marketing (SG\&A) to sales \\
EMPF & A measure of employee fluctuations \\
CI & Measure of capital intensity (net PPE scaled by total assets) \\
\hline
\end{tabular}

assumed model obey the normal distribution. We used the STATA to conduct the probit model and then we got the marginal influence of prospective strategies on "innovation driven" M\&As. The name and meaning of each variable in model (1) are shown in Table 2.

$$
\begin{aligned}
\text { IA }= & \alpha+\beta_{1} \text { Strategy }+\beta_{2} \text { Pattern }+\beta_{3} \text { Size }+\beta_{4} \text { Leverage } \\
& +\beta_{5} \text { Cashflow }+\beta_{6} \mathrm{CR}+\beta_{7} \text { IBR } \varepsilon .
\end{aligned}
$$

If $\beta_{1}>0$ is significant, the hypothesis is true.

\section{Results}

5.1. Descriptive Statistics. According to Table 3 of the sample data for the industry classification, the manufacturing sector was the most inclined to adopt M\&A measures, with 1657 companies in the manufacturing sector undertaking M\&A in the five years from 2011 to 2016. The education and residential services sectors, on the other hand, were the least likely to adopt an M\&A strategy, with only one firm in these two sectors undertaking an M\&A in the five years.

According to the measurements of business strategic orientation, 6 12 points belong to defensive firms, 13 23 points belong to analytical firms, and $24 \sim 30$ points belong to prospective firms. The main types of all acquirers (acquiring firms) after the strategic scoring are shown in Table 4.

The descriptive statistics of these three types of firms are shown in Table 5.

This paper focuses on the two extremes of business strategic orientation-the impact of prospective and defensive strategies on innovation-driven M\&As-so the observed values in the data sample are the sum of the number of prospective and defensive firms. In this paper, the different business strategies were counted, and the data sample was found to include 125 firms with a prospective strategy, 147 companies with a defensive strategy, and 2597 firms with an analytical strategy. After excluding companies with missing variables, we obtained 223 firms with exploratory or defensive strategies. The data from these firms were analyzed by multiple regression.

Since the dependent variable IA (whether it is an innovation-driven M\&A) and the independent variable Strategy (whether it is a prospective firm) are 0-1 variables, the descriptive statistics in Table 6 only describe control variables. The standard deviation of 1.1592 in the size of the acquiring firm's asset (control variable) shows that there is little difference in the acquiring firm's asset size. The mean value of 21.7079 , the maximum value of 24.66 , and the minimum value of 18.63 indicate that the size of all the acquiring firms is relatively large, and no small firms have become the acquirers. Another control variable, Leverage (asset-liability ratio), is one of the most important indicators of the financial situation of the main acquirer before the M\&A. The mean value of 0.4401 of the leverage shows that the acquirers own relatively good financial solvency below $65 \%$; the standard deviation of 0.2679 indicates that most of the main acquirers have little difference in financial solvency; and most acquirers' asset-liability ratios are below 65\%, which signifies that those major acquirers have quite satisfying financial solvency. Cashflow (ratio of net cash flow to total assets in business activities) reflects the firm's cash flow at a specific time. The mean value, maximum, and minimum of Cashflow are $0.0418,0.3514$, and -0.1487 , respectively, which shows that there is much difference in the cash holding levels of different firms and the average level is relatively low. Through the observation of the data, it can be seen that over half of the acquiring firms have negative cash flow before M\&As. Due to the difference in development methods and phases, the acquiring firms are in a stage of scale expansion and investment development, so it is normal to see the cash flow of some acquiring firms being negative.

Meanwhile, the net operating cash flow is an important indicator of a firm's financial situation, and it is closely related to investment, financing, and other financial behaviors. The relatively high cash ratio helps managers seize favorable opportunities of mergers and acquisitions and further investment in the production and operation of new technologies and products. As a measure of the liquidity of a firm's assets, the higher the CR, the better; generally speaking, the ratio of $2: 1$ is preferable. The mean value of 2.939 for CR indicates the high average financial liquidity of the acquiring firms. Although the extreme value of certain firms (such as 0) results in relatively large standard deviations, it does not affect our observation of the overall current ratio of the acquirers. IBR (increasing rate of business revenue) is greater than 0 , indicating that business revenue has increased. The mean value of IBR of 0.1655 shows that the firms taking M\&As are generally in an upward stage with promising market prospects.

5.2. Regression Results. This paper uses the dprobit command in STATA software to conduct model (1) to calculate the marginal influence of the independent variable on the dependent variable. Table 7 presents the result from estimating the marginal influence of a prospective strategy on the "innovation-driven" M\&As model. Strategy is positive 
TABLE 2: Variable name and meaning.

\begin{tabular}{|c|c|c|}
\hline & Variable & Meaning \\
\hline IA & Dependent variable & $\begin{array}{c}\text { Whether it is innovation-driven M\&A; value: } 0 \text { - } 1 \text {, a value of } 1 \text { for an innovation-driven M\&A event and } 0 \\
\text { otherwise }\end{array}$ \\
\hline Strategy & $\begin{array}{l}\text { Independent } \\
\text { variable }\end{array}$ & Whether it is a prospective firm; value: $0-1,1$ for a prospective firm and 0 otherwise \\
\hline $\begin{array}{l}\text { Pattern } \\
\text { Size } \\
\text { Leverage } \\
\text { Cashflow } \\
\text { CR } \\
\text { IBR }\end{array}$ & Control variable & $\begin{array}{l}\text { Nature of property right. } 1 \text { for state-owned firm and } 0 \text { for non-state-owned firm } \\
\text { Firm's size, expressed as the natural logarithm of total assets } \\
\text { Assets-liability ratio } \\
\text { Net cash flow from business activities } \\
\text { Current ratio } \\
\text { Increasing rate of business revenue }\end{array}$ \\
\hline
\end{tabular}

TABLE 3: Industries statistics.

\begin{tabular}{lc}
\hline Industry & Number of firms \\
\hline Manufacturing & 1657 \\
Information transmission, software, and information technology service & 260 \\
Wholesale and retail trade & 156 \\
Real estate & 144 \\
Electricity, heat gas, and water production and supply & 110 \\
Mining & 94 \\
Construction & 81 \\
Transportation, warehousing, and postal services & 81 \\
Culture, sports, and entertainment & 69 \\
Finance & 61 \\
Agriculture, forestry, animal husbandry, and fishery & 42 \\
Leasing and business service & 40 \\
Water conservancy, environment, and public facilities management & 27 \\
Synthesis & 17 \\
Scientific research and technology service & 14 \\
Accommodation and catering & 9 \\
Health and social work & 5 \\
Education & 1 \\
Resident service, repairs, and other services & 1 \\
Total & 2869 \\
\hline
\end{tabular}

TABLE 4: Statistics types of firms.

\begin{tabular}{lccc}
\hline Strategy type & Prospective & Defensive & Analytical \\
\hline No. of firms & 125 & 147 & 2597 \\
\hline
\end{tabular}

TABLE 5: Score statistics of different firm strategies.

\begin{tabular}{|c|c|c|c|c|c|}
\hline Variable & Observed value & Mean value & Standard deviation & Maximum & Minimum \\
\hline Prospective & 125 & 24.96 & 1.2789 & 30 & 24 \\
\hline Defensive & 147 & 11.2449 & .9406 & 12 & 9 \\
\hline Analytical & 2597 & 17.8691 & 2.7499 & 23 & 13 \\
\hline
\end{tabular}

TABLE 6: Descriptive statistics of variables.

\begin{tabular}{|c|c|c|c|c|c|}
\hline Variable & Observed value & Mean value & Standard deviation & Maximum & Minimum \\
\hline Innovation & 223 & 0.3767 & 0.4856 & 1 & 0 \\
\hline Strategy & 223 & 0.4574 & 0.4993 & 1 & 0 \\
\hline Size & 223 & 21.7079 & 1.1592 & 24.66 & 18.63 \\
\hline Leverage & 223 & 0.4401 & 0.2679 & 1.4 & 0.03 \\
\hline Cashflow & 223 & 0.0418 & 0.0724 & 0.3514 & -0.1487 \\
\hline CR & 223 & 4.0054 & 6.4359 & 36.5742 & 0 \\
\hline IBR & 223 & 0.1655 & 0.3156 & 2.2921 & -0.9332 \\
\hline
\end{tabular}


Table 7: Probit regression result of model (1).

\begin{tabular}{lccc}
\hline Independent variable & & Dependent variable IA \\
& Rate of change $\mathrm{d} x / \mathrm{d} f$ & $P$ value & $Z$ value \\
\hline Strategy & $0.2039^{* * *}$ & 0.010 & 2.59 \\
Size & $-0.0872^{* *}$ & 0.011 & -2.55 \\
Leverage & $-0.4420^{* *}$ & 0.015 & -2.44 \\
Cashflow & $0.8434^{*}$ & 0.096 & -0.67 \\
CR & -0.0006 & 0.930 & -0.09 \\
IBR & -0.1241 & & -0.98 \\
Pseudo $R^{2}$ & 0.1403 & \\
$\mathrm{n}$ & 223 & \\
LR chi ${ }^{2}(6)$ & 41.45 & \\
Prob $>$ chi $^{2}$ & 0.0000 & & \\
\hline
\end{tabular}

*** $P<0.001,{ }^{* *} P<0.01$, and ${ }^{*} P<0.05$.

and significant in IA $(P<0.05)$, and the positive coefficient estimate for strategy in IA is 0.2039 , which is consistent with hypothesis 1 that prospectors are more likely to conduct innovation-driven M\&A than defenders.

There is a negative correlation between the control variable Size (firm size of the acquirer) and innovationdriven M\&As. Small firms are more likely to engage in innovative activities or development paths than large firms because many factors are involved in project selection and capital investment in large firms. The innovations progress and decision efficiency are not as good as those of small businesses. As a result, to a certain extent, the firm's scale may restrict the situation of innovation-driven M\&As. Therefore, it is meaningful to conclude that the control variable size is significantly negatively correlated with the dependent variable. Therefore, with leverage, firms with high asset-liability ratios will be more cautious when investing in M\&As and will even turn down M\&As when they cannot afford the investment spending on M\&As.

5.3. Robustness Test. This paper changes the proxy variable of independent variable to test the robustness of the regression result by using the specific score of the business strategy to replace the $0-1$ variable. With the dependent variable and the control variables remaining unchanged, the robustness test is performed by conducting the logistic regression analysis of the sample data. The probit regression result is presented in Table 8, which shows that the independent variable Strategy still had a positive correlation effect on the dependent variable IA and is significant in the case of $P<0.05$. The significance of other control variables does not change. Prospective strategy is still positively related to innovation-driven M\&As.

5.4. Mediating Effects Analysis. The innovation activities in the M\&A field are very active. Through manually reading the announcement text of M\&As, we conclude in Table 4 that $37.3 \%$ of M\&As are innovation-driven, intending to acquire new products and technologies from the merged firms or expand into new business areas. Such M\&As are innovation-driven, and there are distinct characteristics of innovation in the M\&As.

As shown in Figure 2, the paper argues that business strategy cannot directly influence innovation drive and that a mediating variable acts as a bridge between innovationdriven M\&A and business strategic orientation to transmit this influence. It has become a common management practice to use the number of patents to measure a firm's level of innovation or innovation performance [46]. Since the 1960s, the number of patents has been widely used in studies measuring the level of innovation of firms [47-51]. Since the number of patents is strongly correlated with firms' innovation capability and R\&D investment [52], we use the number of patents to indicate firms' innovation level.

This paper further tests the effect of business strategies on innovation-driven M\&As using Baron and Kenny's [53] causal step approach and Sobel's [54] coefficient product method. Safi et al. [27] tested the impact of strategy on the market through a mediating effects model with the risk of stock price collapse as a mediating variable. Based on the previous studies, this paper examines if prospective strategies influence innovation level and if innovation level influences innovation-driven M\&As by using model (3) and model (4), respectively. According to the probit regression analysis of model (1), this paper has already found a positive correlation between prospective strategy and innovation-driven M\&As; that is, $\beta_{1}=0.2039, P<0.001$. Model (2) is actually the same model as model (1) but in order to explain the mediating effect more clearly, we list model (1) here as model (2) to constitute the mediating effect model (Figure 2) with model (3) and model (4). The dependent variable in the model (3) is the innovation level, and we take the Patent (No. of patent grants) as the proxy variable of the dependent variable. The independent variable and the control variable remain consistent with model (2). OLS multiple regression analysis is used to test hypothesis 2 that whether prospective business strategies are more likely to have a higher innovation level than defensive business strategies. In model (4), we take IA as the independent variable and take Patent as the dependent variable, and other variables remain consistent with model (2). Model (5) is generated by adding the innovation level to model (2) as a mediating variable. Then, we conduct a logistic regression through the probit model (5). The probit regression results of model (5) are shown in Table 9, resulting in $\beta_{1}^{\prime}=0.1773$ and $P=0.035$. Compared to $\beta_{1}=0.2309$ and $P=$ 0.01 in Table 7 , we found that the significance level of the model decreases, and the impact coefficient becomes smaller 
TABle 8: Probit regression result of the robustness test.

\begin{tabular}{lccc}
\hline Independent variable & & Dependent variable IA \\
& Rate of change $\mathrm{d} x / \mathrm{d} f$ & $P$ value & $Z$ value \\
\hline Strategy & $0.0175^{* * *}$ & 0.002 & 3.09 \\
Size & $-0.1232^{* * *}$ & 0.002 & -3.10 \\
Leverage & $-0.0498^{* *}$ & 0.019 & -2.34 \\
Cashflow & $0.0000^{* *}$ & 0.039 & 2.07 \\
CR & -0.0003 & 0.959 & -0.05 \\
IBR & -0.1365 & & -1.08 \\
Pseudo $R^{2}$ & 0.1566 & \\
N & 223 & \\
LR chi ${ }^{2}(6)$ & 46.26 & \\
Prob $>$ chi $^{2}$ & 0.0000 &
\end{tabular}

${ }^{* * *} P<0.001,{ }^{* *} P<0.01$, and ${ }^{*} P<0.05$.

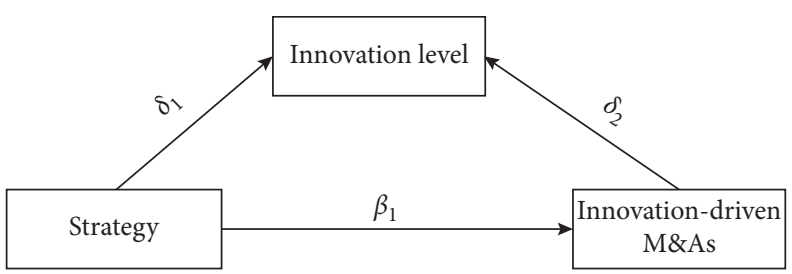

FIGURE 2: Schematic diagram of mediating effect.

Table 9: Probit regression results of model (5).

\begin{tabular}{lccc}
\hline Independent variable & & Dependent variable IA \\
& Rate of change $\mathrm{d} x / \mathrm{d} f$ & $P$ value & $Z$ value \\
\hline Strategy & $0.1773^{* *}$ & 0.035 & 2.11 \\
Patent & 0.0003 & 0.360 & 0.91 \\
Size & $-0.0912^{* * *}$ & 0.008 & -2.64 \\
Leverage & $-0.4584^{* *}$ & 0.012 & -2.52 \\
Cashflow & 0.8061 & 0.113 & 1.58 \\
CR & -0.0003 & 0.962 & -0.05 \\
IBR & -0.1231 & 0.335 \\
Pseudo $R^{2}$ & 0.1435 & & -0.96 \\
$\mathrm{n}$ & 223 & & \\
LR chi ${ }^{2}(7)$ & 42.40 & & \\
Prob $>$ chi $^{2}$ & 0.0000 & & \\
\hline
\end{tabular}

${ }^{* * *} P<0.001,{ }^{* *} P<0.01$, and ${ }^{*} P<0.05$.

after the inclusion of mediating variables. Through Baron and Kenney's (1986) step test for mediating effects, we conclude that business strategy influences innovation-driven M\&A through the innovation level.

We conduct logistic regression to examine the value of $\delta_{2}$ in model (4), and the variables' name and meaning are shown in Table 2. According to the regression results shown in Table $10, \delta_{1}=85.9697$ and $P=0.000$, which is consistent with hypothesis 2. As shown in Table 11, $\delta_{2}=0.0005$, so $\delta_{1} * \delta_{2} \neq 0$ and the mediating effect is significantly verifying hypothesis 3 .

$$
\begin{gathered}
\text { IA }=\alpha+\beta_{1} \text { Strategy }+\beta_{2} \text { Pattern }+\beta_{3} \text { Size }+\beta_{4} \text { Leverage }+\beta_{5} \text { Cashflow }+\beta_{6} \mathrm{CR}+\beta_{7} \mathrm{IBR}+\varepsilon, \\
\text { Patent }=\alpha+\delta_{1} \text { Strategy }+\beta_{2} \text { Pattern }+\beta_{3} \text { Size }+\beta_{4} \text { Leverage }+\beta_{5} \text { Cashflow }+\beta_{6} \mathrm{CR}+\beta_{7} \mathrm{IBR}+\varepsilon, \\
\mathrm{IA}=\alpha+\delta_{2} \text { Patent }+\beta_{2} \text { Pattern }+\beta_{3} \text { Size }+\beta_{4} \text { Leverage }+\beta_{5} \text { Cashflow }+\beta_{6} \mathrm{CR}+\beta_{7} \mathrm{IBR}+\varepsilon, \\
I A=\alpha+\beta_{1}^{\prime} \text { Strategy }+\delta_{2} \text { Patent }+\beta_{2} \text { Pattern }+\beta_{3} \text { Size }+\beta_{4} \text { Leverage }+\beta_{5} \text { Cashflow }+\beta_{6} \mathrm{CR}+\beta_{7} \mathrm{IBR}+\varepsilon .
\end{gathered}
$$


TABLE 10: OLS multivariate regression results of model (3).

\begin{tabular}{lccc}
\hline \multirow{2}{*}{ Independent variable } & \multicolumn{3}{c}{ Dependent variable patent } \\
& Regression coefficient & $P$ value & $t$ value \\
\hline Strategy & $85.9697^{* * *}$ & 0.000 & 5.66 \\
Size & $13.0396^{* *}$ & 0.043 & 2.03 \\
Leverage & 32.6086 & 0.322 & 0.99 \\
Cashflow & 152.5638 & 0.188 & 1.57 \\
CR & -1.4092 & 0.261 & -1.13 \\
IBR & -19.1461 & 0.389 & -0.86 \\
R-squared & 0.1934 & & \\
Sample size & 223 & & \\
Prob $>$ F & 0.0000 & & \\
\hline
\end{tabular}

${ }^{* * *} P<0.001,{ }^{* *} P<0.01$, and ${ }^{*} P<0.05$.

TABle 11: Probit regression results of model (4).

\begin{tabular}{lccc}
\hline \multirow{2}{*}{ Independent variable } & \multicolumn{3}{c}{ Dependent variable IA } \\
& Rate of change $\mathrm{d} x / \mathrm{d} f$ & $P$ value & $Z$ value \\
\hline Patent & $0.0005^{*}$ & 0.093 & 1.68 \\
Size & $-0.0736^{* *}$ & 0.028 & -2.20 \\
Leverage & $-0.5978^{* * *}$ & 0.000 & -3.49 \\
Cashflow & 0.5612 & 0.252 & 1.15 \\
CR & -0.0000 & 0.994 & 0.01 \\
IBR & -0.0827 & 0.499 & -0.68 \\
Pseudo $R^{2}$ & 0.1282 & & \\
n & 223 & & \\
LR chi ${ }^{2}(6)$ & 37.89 & & \\
Prob $>$ chi $^{2}$ & 0.0000 & & \\
${ }^{* * *} P<0.001,{ }^{* *} P<0.01$, and ${ }^{*} P<0.05$. &
\end{tabular}

\section{Discussion and Conclusion}

6.1. Discussion. This article examines the correlation between firm strategy and innovation-driven M\&As. However, after understanding the impact of strategy on innovationdriven M\&As, it is impossible to know whether such innovation-driven M\&As have brought more significant benefits to firms than general M\&As, and nor do we know whether the national innovation-driven transformation has contributed to social-economic development. The performance of innovation-driven M\&As should be further studied. Although the purpose of this paper is to clarify the relationship between firm strategy and innovation-driven M\&As, this relationship may be time-sensitive. This correlation may change over time and market changes and thus become different from the current conclusion.

6.2. Implications. This study links three types of research literature: innovation-driven theory and business strategy theory from management, and M\&A from accounting literature.

The contribution of this paper is reflected in the following aspects: Firstly, it broadens the application of business strategy in accounting research. Previous research on business strategy is often focused on compensation [23], stock price [10,27], firm performance [55], risk management $[16,17]$, and audit effort $[22,30]$. This paper started with M\&A investment and focused on innovation-driven M\&As, which conducted a preliminary exploration for the future indepth study of the impact of firm's business strategy on M\&As. Secondly, the literature on M\&As has been enriched. Previous research has explored the M\&A performance $[3,13,40]$ and innovation in M\&As [34] and regarded M\&A as an investment strategy [4] or strategy matching of technology merger [13], but the influence of the firm's business strategy was neglected. By researching the influence of prospective strategy and defensive strategy on innovationdriven M\&As, this paper deepens the understanding of innovation-driven M\&As from a strategic perspective. It provides a method to predict the possibility of innovationdriven M\&A by measuring business strategy.

6.3. Conclusions and Limitations. Based on the strategyoriented quantification methods of Bentley et al. (2013) [22], this paper studied the relationship between business strategy and innovation-driven M\&As, taking the 2726 M\&A events that occurred in 2011-2016 as research samples. The M\&A events of prospective firms and defensive firms were extracted by strategic scoring, and 223 acquiring firms' data were analyzed by logistic regression. The following three conclusions were reached: Firstly, firms that adopt prospective strategy are more inclined to take innovation-driven M\&As than those that adopt a defensive strategy, which is consistent with the previous research result that prospective strategy firms are focused on innovation [19] and more likely to overinvest [41], undertaking the risk of investment. Secondly, the number of prospective and defensive firms in China is almost equal, and most firms belong to the analytical type which lies between the above two types, but it is not clear which type they will follow then. Thirdly, the strategy influences innovation-driven M\&A through the mediator variables of innovation level. Previous research has proved that business strategy influences innovation level [43] and the innovation level of acquiring firms is influenced by technology-based mergers and acquisitions [34].

However, there are some limitations to this study. When we use the level of innovation as a mediating variable, we find that business strategy has a direct effect on innovationdriven M\&A, but the rate of change of the level of innovation on M\&A is relatively low. Our approach of using the number of patents as a proxy variable for a firm's innovation level is also simplistic, and a more comprehensive measure of innovation level should be constructed to consider a firm's overall level of innovation. Another limitation is the potential for noise when we assess the type of M\&A of firms. When we study the texts of corporate M\&A announcements, we mainly choose to manually read and screen them to distinguish between the types of M\&A. This research approach may run the risk of overlooking important information and misinterpreting corporate texts, leading to misclassification of M\&A types for some companies. In further research, we can use machine learning techniques for screening and identification [56].

Based on our study, future research can continue to explore whether other mediating variables exist in the effect of business strategy on innovation-driven M\&A, as the effect 
of innovation level on innovation-driven M\&A is not very significant in the regression results of this paper. Another research direction could be to further observe whether firms adopting exploratory strategies gain after innovation-driven M\&A.

\section{Data Availability}

All the data used in this paper are directly given in the tables of this paper, and there are no other external data.

\section{Disclosure}

Portions of this work were presented at the Proceedings of the 53rd Hawaii International Conference on System Sciences in 2020, "Research on the Impact of Business Strategy on Knowledge-Transfer Merger and Acquisition with Innovation Level as the Mediator Variable" [55].

\section{Conflicts of Interest}

The authors declare that they have no conflicts of interest.

\section{Acknowledgments}

This study was supported by Zhejiang Philosophy and Social Science Planning Project (grant number: 22NDQN209YB).

\section{References}

[1] Chinadaily, "President Xi jinping's remarks at 13th BRICS Summit,"Beijing, Chinahttps://www.chinadaily.com.cn/a/ 202109/10/WS613aaf2fa310efa1bd66e8a5.html.

[2] H. Zhang and S. Xu, "The innovation-driven impact on economic structure transition. The case of China," International Journal of Management and Economics, vol. 53, no. 4, pp. 9-26, 2017.

[3] M. Baker and S. Savaşoglu, "Limited arbitrage in mergers and acquisitions," Journal of Financial Economics, vol. 64, no. 1, pp. 91-115, 2002.

[4] M. S. Hossain, "Merger \& Acquisitions (M\&As) as an important strategic vehicle in business: thematic areas, research avenues \& possible suggestions," Journal of Economics and Business, vol. 116, Article ID 106004, 2021.

[5] A. Tiwari and G. Shukla, "Emerging trends in cross-border mergers and their tax implications in India: a critical appraisal," Brics Law Journal, vol. 8, no. 1, pp. 116-134, 2021.

[6] E. Battisti, M. Christofi, D. Vrontis, and N. Nirino, "Past, present, and future of mergers and acquisitions in the MENA region: a systematic review and integrative framework," International Studies of Management \& Organization, vol. 51, no. 3, pp. 276-296, 2021.

[7] J. Kwon, C. Kim, and K. C. Lee, "Moderating effect of the continental factor on the business strategy and M\&A performance in the pharmaceutical industry for sustainable international business," Sustainability, vol. 12, no. 12, p. 4985, 2020.

[8] A. B. Chui and W. Ip, "Improving merger and acquisition decision-making using fuzzy logic and simulation," International Journal of Engineering Business Management, vol. 9, Article ID 184797901771152, 2017.

[9] D. Filipovic, N. Podrug, and H. Bujanovic, "Mergers and acquisitions: the case of Croatia," in Proceedings of the 5th
International Scientific Conference on Entrepreneurship and Macroeconomic Management: Reflections on the World in Turmoil, pp. 733-752, Pula, Croatia, March 2011.

[10] M. Lubatkin, "Merger strategies and stockholder value," Strategic Management Journal, vol. 8, no. 1, pp. 39-53, 1987.

[11] P. Barai and P. Mohanty, "Role of industry relatedness in performance of Indian acquirers-Long and short run effects," Asia Pacific Journal of Management, vol. 31, no. 4, pp. 1045-1073, 2014.

[12] H. Singh and C. A. Montgomery, "Corporate acquisition strategies and economic performance," Strategic Management Journal, vol. 8, no. 4, pp. 377-386, 1987.

[13] W. Lv, J. Qi, L. Chen, and J. Feng, "Enterprise strategy matching of technology merger and performance under competition-cooperation environment," International Journal of Technology Management, vol. 84, no. 3/4, pp. 248-266, 2020.

[14] Q. Liu, X. Zhang, and Y. Li, “The influence of information cascades on online reading behaviors of free and paid e-books," Library \& Information Science Research, vol. 42, no. 1, Article ID 101001, 2020.

[15] C. Park, "Prior performance characteristics of related and unrelated acquirers," Strategic Management Journal, vol. 24, no. 5, pp. 471-480, 2003.

[16] J. P. Haug, U. Pidun, and D. zu Knyphausen-Aufsess, "Cui bono? An empirical investigation into risk benefits of corporate diversification," Strategic Organization, vol. 16, no. 4, pp. 429-450, 2018.

[17] M. Safayet, M. Islam, and S. Ahmed, "A case study on risk management in existing construction project in Bangladesh," Journal of Logistics, Informatics and Service Science, vol. 5, no. 1, pp. 1-16, 2018.

[18] Y. Li and L. Zhang, "Do online reviews truly matter? A study of the characteristics of consumers involved in different online review scenarios," Behaviour \& Information Technology, vol. 40, no. 13, pp. 1448-1466, 2020.

[19] R. E. Miles and C. C. Snow, Organizational Strategy, Structure, and Process, Stanford University Press, Palo Alto, CA, USA, 2003.

[20] R. E. Miles, C. C. Snow, A. D. Meyer, and H. J. Coleman Jr, "Organizational strategy, structure, and process," Academy of Management Review, vol. 3, no. 3, pp. 546-562, 1978.

[21] M. E. Porter, "Competitive strategy," Measuring business excellence, vol. 1, pp. 12-17, 1997.

[22] K. A. Bentley, T. C. Omer, and N. Y. Sharp, "Business strategy, financial reporting irregularities, and audit effort," Contemporary Accounting Research, vol. 30, no. 2, pp. 780-817, 2013.

[23] C. D. Ittner, D. F. Larcker, and M. V. Rajan, "The choice of performance measures in annual bonus contracts," The Accounting Review, vol. 72, no. 2, pp. 231-255, 1997.

[24] B. T. Laugen, H. Boer, and N. Acur, "The new product development improvement motives and practices of Miles and Snow's prospectors, analysers and defenders," Creativity and Innovation Management, vol. 15, no. 1, pp. 85-95, 2006.

[25] O. C. Walker, H. W. Boyd, and J.-C. Larreche, Marketing Strategy: Planning and Implementation, Richard d Irwin, Homewood, IL, USA, 1996.

[26] S. M. Shortell and E. J. Zajac, "Perceptual and archival measures of Miles and Snow's strategic types: a comprehensive assessment of reliability and validity," Academy of Management Journal, vol. 33, no. 4, pp. 817-832, 1990.

[27] A. Safi, Y. Chen, A. Qayyum, and S. Wahab, "Business strategy, market power, and stock price crash risk: evidence from China," Risk Management, vol. 21, 2021. 
[28] E. Magerakis and A. Habib, "Business strategy and environmental inefficiency," Journal of Cleaner Production, vol. 302, Article ID 127014, 2021.

[29] C. Liu and D. Kong, "Business strategy and sustainable development: evidence from China," Business Strategy and the Environment, vol. 30, no. 1, pp. 657-670, 2021.

[30] J. Choi and H. J. Park, "Business strategy and audit effortsfocusing on audit report lags: an empirical study in korea," Journal of Asian Finance, Economics and Business, vol. 8, no. 7, pp. 525-532, 2021.

[31] E. Autio and T. Laamanen, "Measurement and evaluation of technology transfer: review of technology transfer mechanisms and indicators," International Journal of Technology Management, vol. 10, no. 7-8, pp. 643-664, 1995.

[32] M. Fontes and R. Coombs, "Contribution of new technologybased firms to the strengthening of technological capabilities in intermediate economies," Research Policy, vol. 30, no. 1, pp. 79-97, 2001.

[33] M. Petraite, "Linking external and internal R\&D and experience based knowledge flows for innovation via organisational design elements," in Proceedings of the European Conference on Knowledge Management, pp. 543-551, Kaunas, Lithuania, September 2013.

[34] P. C. Ensign, C. D. Lin, S. Chreim, and A. Persaud, "Proximity, knowledge transfer, and innovation in technologybased mergers and acquisitions," International Journal of Technology Management, vol. 66, no. 1, pp. 1-31, 2014.

[35] Z. Halili, "Identifying and ranking appropriate strategies for effective technology transfer in the automotive industry: evidence from Iran," Technology in Society, vol. 62, Article ID 101264, 2020.

[36] G. Ahuja and R. Katila, "Technological acquisitions and the innovation performance of acquiring firms: a longitudinal study," Strategic Management Journal, vol. 22, no. 3, pp. 197-220, 2001.

[37] J. Bena and K. Li, "Corporate innovations and mergers and acquisitions," The Journal of Finance, vol. 69, no. 5, pp. 1923-1960, 2014.

[38] O. Granstrand, E. Bohlin, C. Oskarsson, and N. Sjöberg, "External technology acquisition in large multi-technology corporations," R \& D Management, vol. 22, no. 2, pp. 111-134, 1992.

[39] P. C. Kalafut and J. Low, "The value creation index: quantifying intangible value," Strategy \& Leadership, vol. 29, no. 5, 2001.

[40] A. Agrawal, J. F. Jaffe, and G. N. Mandelker, "The post-merger performance of acquiring firms: a Re-examination of an anomaly," The Journal of Finance, vol. 47, no. 4, pp. 1605-1621, 1992.

[41] F. Navissi, V. Sridharan, M. Khedmati, E. K. Lim, and E. Evdokimov, "Business strategy, over- (under-) investment, and managerial compensation," Journal of Management Accounting Research, vol. 29, no. 2, pp. 63-86, 2017.

[42] N. Rajagopalan, "Strategic orientations, incentive plan adoptions, and firm performance: evidence from electric utility firms," Strategic Management Journal, vol. 18, no. 10, pp. 761-785, 1997.

[43] R. Li, Y. Cui, and Y. Zheng, "The impact of corporate strategy on enterprise innovation based on the mediating effect of corporate risk-taking," Sustainability, vol. 13, no. 3, p. 1023, 2021.

[44] A. Seru, "Firm boundaries matter: evidence from conglomerates and R\&D activity," Journal of Financial Economics, vol. 111, no. 2, pp. 381-405, 2014.
[45] J. M. Wooldridge, "Cluster-sample methods in applied econometrics," The American Economic Review, vol. 93, no. 2, pp. 133-138, 2003.

[46] A. J. Ikechukwu, "Assessment of organizational performance of private manufacturing companies: the impact of supply chain management responsiveness," Journal of System and Management Sciences, vol. 9, no. 3, pp. 26-44, 2019.

[47] F. Li, P. Andries, M. Pellens, and J. Xu, "The importance of large firms for generating economic value from subsidized technological innovation: a regional perspective," Technological Forecasting and Social Change, vol. 171, Article ID 120973, 2021.

[48] L. Ponta, G. Puliga, and R. Manzini, "A measure of innovation performance: the Innovation Patent Index," Management Decision, vol. 59, no. 13, pp. 73-98, 2021.

[49] F. M. Scherer, "Firm size, market structure, opportunity, and the output of patented inventions," The American Economic Review, vol. 55, no. 5, pp. 1097-1125, 1965.

[50] B. H. Hall, Z. Griliches, and J. A. Hausman, "Patents and R and D: is there a lag?" International Economic Review, vol. 27, no. 2, pp. 265-283, 1986.

[51] Q. Liu, B. Zhang, L. Wang, X. Zhang, and Y. Li, "Information cascades and online shopping," Journal of Global Information Management, vol. 29, no. 3, pp. 26-45, 2021.

[52] L. Ponta, G. Puliga, L. Oneto, and R. Manzini, "Innovation capability of firms: a big data approach with patents," in Proceedings of the INNS Big Data and Deep Learning Conference, pp. 169-179, Springer, Sestri Levante, Italy, April 2019.

[53] R. M. Baron and D. A. Kenny, "The moderator-mediator variable distinction in social psychological research: conceptual, strategic, and statistical considerations," Journal of Personality and Social Psychology, vol. 51, no. 6, pp. 11731182, 1986.

[54] M. E. Sobel, "Asymptotic confidence intervals for indirect effects in structural equation models," Sociological Methodology, vol. 13, pp. 290-312, 1982.

[55] T. Dalwai and M. Salehi, "Business strategy, intellectual capital, firm performance, and bankruptcy risk: evidence from Oman's non-financial sector companies," Asian Review of Accounting, vol. 29, no. 3, pp. 474-504, 2021.

[56] Y.-1. Sun and D.-1. Zhang, "Machine learning techniques for screening and diagnosis of diabetes: a survey," Tehnički Vjesnik, vol. 26, no. 3, pp. 872-880, 2019. 